\title{
Formal description of conceptual relationship with a view to implementing them in the ontology editor Protégé
}

\author{
Nava Maroto and Amparo Alcina \\ In this article we present a catalogue of conceptual relationships in which each relationship \\ is defined formally in terms of its properties and the nature of the conceptual classes \\ involved. By making explicit the conceptual relationships of the catalogue using the \\ standard ontology editor Protégé we should be able to retrieve conceptual knowledge in an \\ onomasiological way using the Queries function of the editor. In the final part of the article \\ we present a sample query taken from the analysis of the terminology of finished ceramic \\ products in order to show how information about relationships can be retrieved.
}

Keywords: conceptual relationships, ontologies, onomasiological queries, ceramic industry.

\section{Introduction}

In this article ${ }^{1}$ we propose a formal way to represent conceptual relationships with a view to implementing them in a standard ontology editor.

This research is part of the TXTCERAM ${ }^{2}$ and ONTODIC ${ }^{3}$ projects, which are being carried out by the TecnoLeTTra Team at the Universitat Jaume I in Castellón (Spain). The TXTCERAM project's main objective is to create an electronic corpus of specialized texts from the field of ceramics which can be used to test the efficiency of certain software tools in the design of an integrated computer-assisted system for elaborating and consulting terminologies. The aim of the ONTODIC project is to propose a systematic methodology for the elaboration of onomasiological terminological dictionaries using an ontology editor, as well as other tools. As part of these projects we are currently developing a dictionary of ceramics terminology that allows the user to make queries based on the meaning and not only through the lemma. 
Most computer tools for terminology management and electronic dictionaries largely fail to take into account the systematicity of specialized knowledge, because the conceptual information is reflected in a dispersed way in the definitions in natural language.

We set out from the hypothesis that, if we can make the relationships between concepts explicit and represent them in a structured way, we will then be able to formalize the knowledge about an area of speciality in such a way that it can be retrieved using a computer; in other words, we will be able to make onomasiological queries using knowledge about relationships.

Over the last two decades, experts in knowledge engineering have been working on the structuring of knowledge using ontologies. An ontology can be defined as a structured representation of knowledge which is used to store generally agreed information about worldwide phenomena in an explicit way (Gruber 1995). These explicit representations are reached through the consensus of particular groups of users and aim at being reused and shared across software applications (Gómez Pérez et al. 2004: 8).

The development of ontologies is based upon different ontological languages and modelling techniques, such as frames logics, descriptive logics or conceptual graphs. Even though an exhaustive description of these languages excedes the scope of this paper, ${ }^{4}$ we would like to emphasize that, whatever the ontological language used, the relationships that associate concepts in an ontology are a crucial element in the structuring of knowledge. In frames logics, for example, relationships represent the association of two concepts within a domain, whereas in descriptive logics roles are used to establish binary associations between concepts.

Gómez Pérez et al. (2004) distinguish among different types of ontologies depending on the subject of the conceptualization and the richness of their internal structure. The most outstanding are knowledge representation ontologies, top-level ontologies, linguistic ontologies and domain ontologies:

a) A knowledge representation (KR) ontology gathers the modelling primitives used to formalize knowledge in a KR paradigm. Some examples are the Frame Ontology (Gruber 1995), the RDF ontology (Lassila and Swick 1999) or the OWL KR ontology (Dean and Schreiber 2004). 

are common across domains and give general notions under which all the concepts in existing ontologies should be linked. Some examples of this type are the top-level ontology of universals (Guarino and Welty 2000), the Basic Formal Ontology (BFO, Smith 1998) or Sowa's top-level ontology (Sowa 2000).

c) A linguistic ontology aims at describing semantic constructs bound to the semantics of linguistic units. To this type belong ontologies such as WordNet (Fellbaum 1998) or Mikrokosmos (Nirenburg and Raskin 2004).

d)

Domain ontologies are reusable vocabularies of the concepts within a domain and their relationships, of the activities taking place in that domain, and of the theories and elementary principles governing that domain. Some examples of this type are the UMLS (Unified Medical Language System) or the EngMath ontology in the domain of medicine and mathematics, respectively.

The construction of ontologies is a very costly task. Therefore, knowledge engineers have developed tools which are useful to carry out the tasks involved in the process (development, evaluation or querying and inference, among others). There is a wide variety of ontology development tools and tool suites that we will not describe in detail in this article. Some of them are ontological language-dependent (such as the Ontolingua Server, described in Farquhar et al. 1997), whereas others are language-independent. In our research we have opted for one of the latter, i.e. Protégé-frames ontology editor (Stanford Medical Informatics 2009). There are several reasons for this choice, such as the fact that it is a free-based editor with a large number of users worldwide which allows for collaborative work, together with the fact that its architecture is open and allows for its extensibility through plug-ins. We consider that these features make this tool suitable for the development of terminological ontologies.

In the light of the brief presentation of ontologies given above, a clear link between ontologies and terminology can be spotted. Both ontologies an terminology aim at a consensual conceptualization of world phenomena, and therefore both disciplines can benefit from each other. That is the reason why, in recent years there has been a shift towards organizing terminological information using ontologies (Gamper et al. 1999; 
Faber 2002; Temmerman and Kerremans 2003; Cabré 2004), as an evolution from terminological knowledge bases (Meyer et al. 1992). Conferences and publications ${ }^{5}$ on terminology devote increasing attention to integrating the development of ontologies in terminology work. Some research groups have developed their own tools to create ontologies from terminologies, such as CAOS (Madsen et al. 2002) and ONTOTERM (Moreno Ortiz 2002). However, in the ONTODIC project the aim is to adapt a standard ontology editor -in our case Protégé-frames (Stanford Medical Informatics 2009)- to the treatment of the relationships between concepts in the terminology used in the ceramic industry (Alcina, in press).

We would like to underline the fact that we are considering the previous works in the field of knowledge engineering, but our purpose is to adapt the technologies and methods suggested to terminological work. We borrow these methods and technologies and try to adapt them to the point of view of the theory and practice of terminology.

In section 2 of this article each conceptual relationship is described in a semi-formal way, stating its arguments, properties and concept classes involved. In section 3 a preliminary test for the implementation of conceptual relationships in Protégé is carried out. In section 4 the advantages and limitations of the model proposed are discussed, and in section 5 the conclusions and the next steps to be taken in order to adapt ontology editors to the formal representation of conceptual relationships are presented.

The examples presented in this article are extracted from the analysis of the TXTCERAM corpus $^{6}{ }^{6}$ and more precisely from the study in context of the terminology of finished ceramic goods. That is the reason why there are some relationships for which we have not found examples in the field of the ceramic industry at this stage of the study.

\section{Formal description of conceptual relationships in terminology}

In order to describe conceptual relationships in a formal way, we conceive them as semantic links between two or more specialized concepts. This definition, put forward by Otman (1996), is expressed by means of the notation: 
where $\boldsymbol{a}$ and $\boldsymbol{b}$ are concepts linked by the relationship $\mathbf{R}$.

In the notation $\boldsymbol{a} \mathbf{R} \boldsymbol{b}$, concepts $\boldsymbol{a}$ and $\boldsymbol{b}$ linked by $\mathbf{R}$ belong to a conceptual class, while $\mathbf{R}$ has certain properties that have consequences in the formal description of each relationship.

In this section, each of the relationships considered (R) is defined in natural language (Section 2.1), then conceptual classes to which $\boldsymbol{a}$ and $\boldsymbol{b}$ may belong are introduced (Section 2.2).

As we mentioned above, the properties of conceptual relationships have implications for their implementation in an ontology editor. For example, the fact that a relationship is transitive or symmetrical should allow for a more economical development of a knowledge database. In section 2.3 the properties considered functional for the implementation of conceptual relationships with the help of a standard ontology editor are presented.

Once we have outlined which elements to consider in the formal description of conceptual relationships, we have devised a template that allows to reflect the nature of $\boldsymbol{a}, \boldsymbol{b}$ and $\mathbf{R}$ in each conceptual relationship (Section 2.4).

\subsection{Catalogue of conceptual relationships}

The catalogue of conceptual relationships presented in this research integrates the proposals by Sager (1990), Feliu (2004) and Dancette and L'Homme (2004), which are completed with the subdivision of meronymic relationships put forward by Winston et al. (1987). This choice is due to the fact that these classifications cover most of the relationships usually considered in terminological work. We have examined other classifications, such as those suggested by Nuopponen (2005) or Weissenhofer (1995), who describe a large number of conceptual relationships. However, at this stage of the research a limited number of relationships were considered, which are nevertheless representative of the conceptual links between specialized concepts. Another reason that has led us to consider the abovementioned classifications is that, especially in Sager, Feliu and Dancette and L'Homme's proposals, the conceptual classes involved in the relationship (entities, activities and properties) can be easily identified. 
Each relationship has been designated in such a way that the name shows the role played by the concepts linked by the relationship, that is, which element accounts for concept $\boldsymbol{a}$ in the notation, and which element is represented by concept $\boldsymbol{b}$ in the notation. For example, the logical relationship that links a more general concept (hypernym) to a more specific one (hyponym) is called in our catalogue HYPERNYM-HYPONYM relationship. We consider that this naming convention -already used by Sager (1990) to name complex relationships- reveals clearly the nature and directionality of the relationship. However, we are aware that some of the names may seem atypical.

The following five groups of relationships have been established: logical relationships, meronymic relationships, sequential relationships, argumental and circumstantial relationships, and other relationships. Each group is subdivided into the subrelationships that have been considered in the study, for which a definition in natural language and some examples from our empirical study are suggested to illustrate the nature of the relationship.

\section{a) Logical relationships}

Logical relationships are based upon the comparison of concepts considering the characteristics they share and those that differentiate them. Following Sager (1990), we distinguish the relationship established between a hypernym and its direct hyponyms (HYPERNYM-HYPONYM) and the one that links the hyponyms of a common hypernym (HYPONYM-HYPONYM).

Table 1 shows the two logical relationships considered and presents an example taken from the terminology of finished ceramic products.

Table 1. Logical relationships

\begin{tabular}{|l|l|l|}
\hline $\begin{array}{l}\text { Name of } \\
\text { relationship }\end{array}$ & Natural language definition & Examples \\
\hline $\begin{array}{l}\text { HYPERNYM- } \\
\text { HYPONYM }\end{array}$ & $\begin{array}{l}\text { Relationship established between a concept } \boldsymbol{a} \\
\text { situated at a higher abstraction level and a } \boldsymbol{b} \\
\text { concept situated at a lower level. }\end{array}$ & $\begin{array}{l}\text { piezámica cerámicaldosa } \\
\text { ceramic floor tile) }\end{array}$ \\
\hline
\end{tabular}




\begin{tabular}{|l|l|l|}
\hline HYPONYM- & $\begin{array}{l}\text { Relationships established between two concepts } \\
\text { HYPONYM }\end{array}$ & $\begin{array}{l}\text { cubrecantos-escuadra } \\
\text { (beads-right angle) } \\
\text { respect to a common hypernym. }\end{array}$ \\
\hline
\end{tabular}

\section{b) Meronymic Relationships}

Meronymic relationships are ontological relationships established between a whole and the constituent parts that compose it. Given the fact that meronymy is a very complex relationship, we have followed the distinction among seven types of meronymic relationships first suggested by Winston et al. (1987) and already used in the field of terminology by authors such as Barrière (2002), Feliu (2004) and Soler and Alcina (2008).

We have added the PART-PART RELATIONSHIP, established between parts that together constitute a whole, regardless of the subtype of meronymic relationship. Table 2 shows the classification of meronymic relationships.

Table 2. Meronymic relationships

\begin{tabular}{|c|c|c|}
\hline Name of relationship & Natural language definition & Examples \\
\hline $\begin{array}{l}\text { FUNCTIONAL } \\
\text { COMPONENT-OBJECT }\end{array}$ & $\begin{array}{l}\text { Relationship established between a component } \\
\text { that fulfils a function in an object and the object it } \\
\text { is part of. }\end{array}$ & $\begin{array}{l}\text { arista- baldosa } \\
\text { (edge-floor tile) }\end{array}$ \\
\hline $\begin{array}{l}\text { MEMBER- } \\
\text { COLLECTION }\end{array}$ & $\begin{array}{l}\text { Relationship established between parts that have } \\
\text { space proximity or social connection with respect } \\
\text { to the whole, no matter the function they fulfil or } \\
\text { the fact that they are situated structurally in a } \\
\text { specific way. }\end{array}$ & $\begin{array}{l}\text { tesela-mosaico } \\
\text { (tesserae-mosaic) }\end{array}$ \\
\hline PORTION-MASS & $\begin{array}{l}\text { Relationship between a part and the whole where } \\
\text { the nature of the part is the same as that of the } \\
\text { whole. }\end{array}$ & $\begin{array}{l}\text { muestra-material } \\
\text { (specimen-material) }\end{array}$ \\
\hline MATERIAL-OBJECT & $\begin{array}{l}\text { Relationship between an intrinsic part and the } \\
\text { whole, from which the part cannot be separated, } \\
\text { because it is consubstantial to the whole. }\end{array}$ & $\begin{array}{l}\text { arcilla-baldosa } \\
\text { cerámica (clay- } \\
\text { ceramic floor tiles) }\end{array}$ \\
\hline STAGE-PROCESS & Relationship established between each of the & etapa de gran fuego- \\
\hline
\end{tabular}

Comentari [ALS1]: Table 2 is not cited in the text. 


\begin{tabular}{|c|c|c|}
\hline Name of relationship & Natural language definition & Examples \\
\hline & phases of an activity and that activity as a whole. & $\begin{array}{l}\text { cocción (high firing- } \\
\text { firing) }\end{array}$ \\
\hline $\begin{array}{l}\text { CHARACTERISTIC- } \\
\text { ACTIVITY }\end{array}$ & $\begin{array}{l}\text { Relationship between the characteristics of an } \\
\text { activity and the complex process in which they } \\
\text { are inscribed. }\end{array}$ & $\begin{array}{l}\text { presecado-proceso } \\
\text { cerámico (predrying- } \\
\text { ceramic process) }\end{array}$ \\
\hline SPACE-AREA & $\begin{array}{l}\text { Relationship established between a spatial area } \\
\text { and the specific localizations inside that area. }\end{array}$ & $\begin{array}{l}\text { región visible-campo } \\
\text { de radiaciones } \\
\text { (visible area- } \\
\text { radiation field) }\end{array}$ \\
\hline PART-PART & $\begin{array}{l}\text { Relationship between the parts that together make } \\
\text { up a whole. }\end{array}$ & $\begin{array}{l}\text { cara vista-arista } \\
\text { (facing tile-edge) }\end{array}$ \\
\hline
\end{tabular}

\section{c) Sequential relationships}

The sequential relationships included in our catalogue are based on a proposal by Feliu (2004). They are established through the localization or succession in space or time of the linked elements. This author identifies two types of sequentiality: spatial sequentiality and temporal sequentiality. The first can, in turn, refer to either localization or direction, and temporal sequentiality can be simultaneous and previous-subsequent. We have adapted the names suggested by Feliu (2004) to our naming proposal, which yields the four types of sequential relationships shown in Table 3.

Table 3. Sequential relationships

\begin{tabular}{|l|l|l|}
\hline Name of relationship & Natural language definition & Examples \\
\hline $\begin{array}{l}\text { CONCEPT-SIMULTANEOUS } \\
\text { CONCEPT (IN SPACE) }\end{array}$ & $\begin{array}{l}\text { Relationship between two concepts that are } \\
\text { situated together in space. }\end{array}$ & $\begin{array}{l}\text { adhesivo- } \\
\text { adherendo } \\
\text { (adhesive- } \\
\text { adherend) }\end{array}$ \\
\hline $\begin{array}{l}\text { CONCEPT-PLACE IT GOES } \\
\text { TO }\end{array}$ & $\begin{array}{l}\text { Relationship between two concepts that shows the } \\
\text { direction in which a specific activity and the place } \\
\text { it goes to. }\end{array}$ & \begin{tabular}{l}
--- \\
\hline
\end{tabular}
\end{tabular}




\begin{tabular}{|l|l|l|}
\hline Name of relationship & Natural language definition & Examples \\
\hline $\begin{array}{l}\text { CONCEPT-SIMULTANEOUS } \\
\text { CONCEPT (IN TIME) }\end{array}$ & $\begin{array}{l}\text { Relationship between two activities or entities that } \\
\text { concur. }\end{array}$ & --- \\
\hline $\begin{array}{l}\text { PREVIOUS CONCEPT- } \\
\text { SUBSEQUENT CONCEPT }\end{array}$ & $\begin{array}{l}\text { Relationship established between two concepts } \\
\text { that are situated consecutively in time. }\end{array}$ & --- \\
\hline
\end{tabular}

\section{d) Argumental and circumstantial relationships}

This label accounts for the conceptual relationships established between predicates and their arguments (argumental relationships), as well as those which indicate the circumstances in which a predicate occurs (circumstantial relationships). The inclusion of this group of relationships is based on a proposal by Dancette and L'Homme (2004), which in turn coincides with the relationships that Sager (1990) calls complex relationships.

The argumental and circumstantial relationships included in our catalogue are exemplified in Table 4.

Table 4. Argumental and circumstantial relationships

\begin{tabular}{|l|l|l|}
\hline $\begin{array}{l}\text { Name } \\
\text { relationship }\end{array}$ & Natural language definition & Examples \\
\hline PROCESS-AGENT & $\begin{array}{l}\text { Relationship between an activity and the } \\
\text { entity that carries out that activity. }\end{array}$ & secado-horno (drying-kiln) \\
\hline PROCESS- & $\begin{array}{l}\text { Relationship between a activity and the } \\
\text { entity on which the activity is carried out. }\end{array}$ & $\begin{array}{l}\text { colocación-baldosa } \\
\text { ceramic floor tile) }\end{array}$ \\
\hline $\begin{array}{l}\text { PROCESS- } \\
\text { PRODUCT }\end{array}$ & $\begin{array}{l}\text { Relationship between a process and the } \\
\text { final product of that process. }\end{array}$ & $\begin{array}{l}\text { engobe-baldosa } \\
\text { (engobe-engobed floor tile) }\end{array}$ \\
\hline PROCESS-STATE & $\begin{array}{l}\text { Relationship between a process and the } \\
\text { final state reached by the patient of the } \\
\text { activity. }\end{array}$ & $\begin{array}{l}\text { extrusión-extrudido } \\
\text { extruded) }\end{array}$ \\
\hline CAUSE-EFFECT & $\begin{array}{l}\text { Relationship between a cause and the } \\
\text { effect it produces. }\end{array}$ & $\begin{array}{l}\text { fricción-abrasión } \\
\text { abrasion) }\end{array}$ \\
\hline PROCESS- & $\begin{array}{l}\text { Relationship between a process and the } \\
\text { instrument used to carry out the process. }\end{array}$ & $\begin{array}{l}\text { colocación con junta-cemento } \\
\text { (tiling with joints-cement) }\end{array}$ \\
\hline
\end{tabular}




\begin{tabular}{|l|l|l|}
\hline $\begin{array}{l}\text { PROCESS- } \\
\text { METHOD }\end{array}$ & $\begin{array}{l}\text { Relationship between a process and the } \\
\text { method used to carry it out. }\end{array}$ & \begin{tabular}{l}
--- \\
\hline OBJECT-USE
\end{tabular} \\
$\begin{array}{l}\text { Relationship between an object and the } \\
\text { function or use to which it is devoted. }\end{array}$ & $\begin{array}{l}\text { (baldosa cerámica-revestimiento } \\
\text { de suelos (floor tile-floor covering) }\end{array}$ \\
\hline
\end{tabular}

\section{e) Other relationships}

There are a number of relationships that do not fit into the four groups described above, but which can occur among specialized concepts, and in the field of the ceramic industry in particular. Their representation is also useful for structuring specialized knowledge in this field.

The first two relationships included in this group stem from the classification of complex relationships proposed by Sager (1990), while associative relationships (ISO 704 2000: 13) can be defined as relationships based upon a thematic link between concepts arising from experience. Table 5 exemplifies this last group of relationships.

Table 5. Other relationships

\begin{tabular}{|l|l|l|}
\hline Name of relationship & Natural language definition & Examples \\
\hline PHENOMENON- & $\begin{array}{l}\text { Relationship between a phenomenon or } \\
\text { characteristic and the unit employed to } \\
\text { express that phenomenon or characteristic. }\end{array}$ & $\begin{array}{l}\text { fuerza de rotura-Newtons } \\
\text { (breaking strength- } \\
\text { Newtons) }\end{array}$ \\
\hline OBJECT- & $\begin{array}{l}\text { Relationship between an entity and a } \\
\text { Characteristic that defines it. }\end{array}$ & $\begin{array}{l}\text { baldosa absarción } \\
\text { absorción de agua } \\
\text { (ceramic floor tile-water } \\
\text { absorption) }\end{array}$ \\
\hline ASSOCIATIVE & $\begin{array}{l}\text { Relationship established by correlation } \\
\text { between two or more concepts which does } \\
\text { not fit into any of the above-mentioned } \\
\text { relationships. }\end{array}$ & $\begin{array}{l}\text { prueba-propiedad de los } \\
\text { materiales (test-property of } \\
\text { materials) }\end{array}$ \\
\hline
\end{tabular}

\subsection{Conceptual classes}


The concepts linked through a relationship are assigned to a class. In their conceptual model, Sager and Kageura (1994) identify four types of concepts: entities, activities, properties and relationships, which can be defined as follows:

a) Entity: A type of concept obtained by the abstraction of elements from experience and reflection whose existence is considered to be independent in space and time. ${ }^{7}$ Entities can be defined separately and are necessary to identify and classify the units of experience and knowledge. All ceramic products (wall tiles, floor tiles), raw materials (clay, stoneware), machinery and their components (oil hydraulic press, single-deck roller kiln), as well as the places where processes occur (dryer) and where products are used (walls, floors) would be examples in the field of ceramics.

b) Activity: A type of concept obtained by the abstraction of processes, operations or events performed by or with entities. Their structure is more complex than that of entities because they can only be carried out with the direct participation of the latter, that is, they can be considered secondary concepts in the sense used in ontology engineering. Some of the activities identified in the field of ceramics are the manufacturing processes (dust pressing, firing) and the tile-laying processes (tiling, thin-set tiling).

c) Property: A type of concept derived from the analysis of the components and characteristics of entities, activities and relationships. Properties are always considered to be associated to other concepts on a first level of abstraction, and they are only constituted as independent concepts on a second level. They allow for the identification of the differences between entities and activities, while they also reflect their features and characteristics. Some examples in our thematic area would be all the characteristics of ceramic products (frost resistance, porosity, color).

d) Relationship: A type of concept obtained from the abstraction of physical and temporal relationships or other types of ontological relationships among objects, and from the logical relationships among entities, relationships and activities. Relationships are the type of concepts that identify the links that exist or have been established between two or more entities, activities or properties, or any combination of the three. Some examples of relationship concepts identified in the field of ceramics are phase (indicates a sequential relationship) and composition (indicates a meronymic relationship). 
Table 6 exemplifies each conceptual class found in the field of ceramics at this stage of our study.

Table 6. Conceptual classes

\begin{tabular}{|l|l|l|}
\hline $\begin{array}{l}\text { Conceptual } \\
\text { class }\end{array}$ & $\begin{array}{l}\text { Subject-specific conceptual classes in the field } \\
\text { of ceramic industry }\end{array}$ & Examples \\
\hline Entities & ceramic products & wall tile, floor tile \\
\cline { 2 - 3 } & raw materials & clay, stoneware \\
\cline { 2 - 4 } & machinery and its components & $\begin{array}{l}\text { oil hydraulic press, single-deck } \\
\text { roller kiln }\end{array}$ \\
\cline { 2 - 4 } & places & dryer, floor, wall \\
\hline Activities & manufacturing processes & dust pressing, firing \\
\cline { 2 - 4 } & tile-laying processes & tiling, thin-set tiling \\
\hline Properties & characteristics of ceramic products & phase, composition \\
\hline Relationships & links among entities, properties and activities & frosity, color \\
\hline
\end{tabular}

Note that we have distinguished between broad conceptual classes and subjectspecific conceptual classes, following the categorisation model put forward by Kageura (2002) for the field of documentation.

We find the conceptual model proposed by Sager and Kageura suitable because of its terminological orientation and because it fits into the types of concepts found in the thematic field of industrial ceramics. In our method for formalizing conceptual relationships we have taken into account the conceptual class to which the concepts linked by each relationship belong (entities, properties, activities), and have implemented these conceptual classes as a top ontology from which all other concepts stem.

\subsection{Properties of conceptual relationships}


Conceptual relationships can be characterized formally in terms of their properties. These properties are relevant in order to make automatic deductions using a program such as an ontology editor. We suggest taking into account transitivity, symmetry, cardinality and the existence of inverse relationships. These properties of relationships have been well defined in the field of lexical semantics by Lyons (1977), Cruse (1986) and Evens (1988), and they have been applied in terminology by authors such as Otman (1996), Feliu (2004) or Oster (2005). They are also used in ontological languages that use descriptive logics, such as OWL, for example.

We will now go on to define these properties, and how accounting for them should facilitate onomasiological queries and the development of conceptual databases. Some examples taken from our empirical research on finished ceramic products are used to illustrate this:

a) Transitivity: A relationship is said to be transitive if it is true that

if $\boldsymbol{a} \mathbf{R} \boldsymbol{b}$ and $\boldsymbol{b} \mathbf{R} \boldsymbol{c}$,

then $\boldsymbol{a} \mathbf{R} \boldsymbol{c}$

For example, the HYPERNYM-HYPONYM relationship is transitive. Therefore, if we consider the concept ceramic part to be a hypernym of ceramic floor tile, and in turn ceramic floor tile is a hypernym of glazed floor tile, it follows that the concept ceramic part is also a hypernym of glazed floor tile. So,

$\begin{array}{llll}\text { if } & \text { ceramic part } & \text { HYPERNYM-HYPONYM } & \text { ceramic floor tile, } \\ \text { and } & \text { ceramic floor tile } & \text { HYPERNYM-HYPONYM } & \text { glazed floor tile } \\ \text { then } & \text { ceramic part } & \text { HYPERNYM-HYPONYM } & \text { glazed floor tile }\end{array}$

Transitivity enables to take advantage of inheritance mechanisms when creating a conceptual database. This means that if the computer understands that the HYPERNYMHYPONYM relationship is transitive, and we have introduced ceramic floor tile as a hypernym of ceramic part, and glazed floor tile as a hyponym of ceramic floor tile, then the system can infer that glazed floor tile is also a hyponym of ceramic part, and therefore should inherit some of its relationships and properties.

b) Symmetry: A relationship is said to be symmetrical if it is true that 
when $\boldsymbol{a} \mathbf{R} \boldsymbol{b}$,

then $\boldsymbol{b} \mathbf{R} \boldsymbol{a}$

For example, the PART-PART relationship among the different parts that make up a whole is symmetrical. Thus, if the concepts tile face and tile back are both parts of the same whole (ceramic floor tile), the relationship is true in both directions. So,

if

\section{tile face PART-PART tile back}

then

\section{tile back PART-PART tile face}

If we are able to state that a relationship is symmetrical, then the computer should be able to infer that the same relationship holds in both directions.

c) Cardinality: The cardinality of a relationship indicates whether it can be established between a concept $\boldsymbol{a}$ and $\boldsymbol{n}$ concepts $\boldsymbol{b}$. This property refers to the number of concepts $\boldsymbol{b}$ that a concept $\boldsymbol{a}$ can be related to by the same relationship R. For example, the relationship MATERIAL-OBJECT is a relationship whose cardinality can be higher than one, that is, the same material can be part of various objects; for example clay is used both in ceramic floor tiles and in the Catalan floor tiles. In this way, if the cardinality of the relationship MATERIAL-OBJECT can be higher than one, then the $\boldsymbol{a}$ concept clay can be related to more than one $\boldsymbol{b}$ concept (ceramic floor tiles, Catalan floor tiles).

However, the HYPONYM-HYPERNYM relationship, for example, has cardinality=1, that is, in our proposal, each concept may only have one hypernym.

d) Inverse relationships: Two relationships are said to be inverse to each other if, for $\boldsymbol{a} \mathbf{R} \boldsymbol{b}$, there is a relationship R' between $\boldsymbol{b}$ and $\boldsymbol{a}\left(\boldsymbol{b} \mathbf{R}^{\prime} \boldsymbol{a}\right)$. For example, the PROCEssPRODUCT relationship has an inverse relationship called PRODUCT-PROCESS. Therefore the concepts extrusion moulding and extruded floor tile are linked through both relationships. So, it holds that

\section{if extrusion moulding PROCESS-PRODUCT extruded floor tile} then extruded floor tile PRODUCT-PROCESS extrusion moulding

If a conceptual relationship has an inverse relationship, then the computer should be able to infer that this relationship holds between the concepts related through the latter. 
2.4. Template for the formal description of conceptual relationships

After having analysed the elements that should be taken into account for each relationship according to the notation $\boldsymbol{a} \mathbf{R} \boldsymbol{b}$, namely, the catalogue of relationships, the nature of concepts $\boldsymbol{a}$ and $\boldsymbol{b}$, and the properties of $\mathbf{R}$, we are ready to formalize each of the relationships in the catalogue in terms of these elements, and this will be helpful in the onomasiological retrieval of information as well as in the development of knowledge bases. The elements for the formal description are reflected in the template shown in Table 7.

Table 7. Template for the formal description of conceptual relationships

\begin{tabular}{|c|c|c|}
\hline \multicolumn{2}{|c|}{ Name of the relationship } & NAME OF RELATIONSHIP (DOMAIN-RANGE) \\
\hline \multicolumn{2}{|c|}{ Natural language definition } & Text in natural language \\
\hline \multirow[t]{2}{*}{ Conceptual classes I } & Domain $(\boldsymbol{a})$ & entity/activity/property \\
\hline & Range $(\boldsymbol{b})$ & entity/activity/property \\
\hline \multirow[t]{4}{*}{ Properties of $\mathbf{R}$} & Transitivity & Yes or No \\
\hline & Symmetry & Yes or No \\
\hline & Cardinality & Number \\
\hline & Inverse relationship & NAME OF INVERSE RELATIONSHIP (RANGE-DOMAIN) \\
\hline \multicolumn{2}{|l|}{ Example } & Example from the TXTCERAM corpus \\
\hline
\end{tabular}

Note that the conceptual classes involved in one relationship may belong to different conceptual classes (entities, properties or activities). However, the value of transitivity and symmetry can be Yes or No, but not both at a time. ${ }^{8}$

In order to elicit these templates, we have considered previous work in this field (especially Feliu 2004). We have then checked the validity of the proposal through the manual analysis of the relationships present in the TXTCERAM corpus.

Table 8 exemplifies the formal description of the argumental relationship PROCESSPRODUCT. 
Table 8. Formal description of the process-product relationship

\begin{tabular}{|l|l|l|}
\hline Name of the relationship & PROCESS-PRODUCT \\
\hline Natural language definition & $\begin{array}{l}\text { Relationship between the process and the final product that } \\
\text { results from it. }\end{array}$ \\
\hline $\begin{array}{l}\text { Conceptual } \\
\text { classes }\end{array}$ & Domain $(\boldsymbol{a})$ & Activity \\
\cline { 2 - 3 } & Range (b) & Entity \\
\hline Properties of $\mathbf{R}$ & Transitivity & No \\
\cline { 2 - 4 } & Symmetry & No \\
\cline { 2 - 4 } & Cardinality & Can be higher than one \\
\cline { 2 - 4 } & Inverse & PRODUCT-PROCESS \\
\hline Example & relationship & \\
\hline
\end{tabular}

As can be seen in Table 8, this relationship is established between concepts belonging to the class activity (i.e. processes) and concepts which belong to the class entity (i.e. products resulting from a process). It is a non-transitive, non-symmetrical relationship whose cardinality can be higher than one, that is, the same activity can be produce different entities. It has an inverse relationship, which is the PRODUCT-PROCESS relationship.

In Annex 1 we include a table that summarizes the formal description of each of the relationships of the catalogue, with examples in Spanish extracted from the empirical analysis of the TXTCERAM corpus.

\section{Implementation of conceptual relationships in the ontology editor Protégé}

Once each conceptual relationship has been described formally in terms of its properties and the conceptual classes that participate in it, an empirical study has been carried out which focuses on finished ceramic products and their related concepts found in the TXTCERAM corpus. 
In this section we present the way in which our formal description model has been used to introduce data into the conceptual database Ontoceram, created using the ontology editor Protégé. It contains 621 concepts arisen from the analysis of finished ceramic products.

Section 3.1 presents the way in which the standard ontology editor Protégé has been used in this research to introduce concepts, relationships and terms in the database Ontoceram. In section 3.2 we offer an example of a preliminary test that shows how our formal description model is suitable for carrying out onomasiological queries using Protégé.

\subsection{Data introduction in Ontoceram using Protégé}

Considering the components and functions of the ontology editor Protégé, in this research we have implemented a model for the introduction of concepts, relationships and terms in the conceptual database Ontoceram.

The information has been introduced in Ontoceram in the following way:

a) Concepts are represented through the Class component of Protégé. Concepts (which may be entities, actions or properties) are organized in a hierarchical way that reflects the relationships between hypernyms and hyponyms. Concepts are thus represented in a hierarchical way through the Class component.

b) Conceptual relationships are represented through the Slot component. This component allows assigning attributes to the concepts expressed through the Class component, thus making these links explicit in Ontoceram. In each slot the relationship properties (transitivity, symmetry, cardinality and inverse relationship) are indicated.

c) Terms are represented through the Instance component. This allows for the retrieval of information using the Queries function of Protégé. The Instance component is normally used in ontological engineering to introduce actual data, that is, the actual objects to which classes refer.

In Figure 1 the concept Baldosa cerámica (Ceramic floor tile) is shown such as it appears in Ontoceram. This concept is a direct hyponym of Producto cerámico acabado 
(Finished ceramic product), thus representing the HYPERNYM-HYPONYM relationship. The concept Baldosa cerámica has been assigned several relationship slots that link this concept to others included in the database. The relationship slots assigned to Baldosa cerámica are CONCEPT-SIMULTANEOUS CONCEPT, CONCEPT-PLACE, OBJECT-CHARACTERISTIC, OBJECT-FUNCTIONAL COMPONENT, OBJECT-MATERIAL, OBJECT-USE and PATIENTPROCESS. The values of these slots are other concepts represented in the conceptual database, such as Revestimiento (lining) (OBJECT-USE), Resistencia a la helada (frost resistance) (OBJECT-CHARACTERISTIC), Canto (edge) (OBJECT-FUNCTIONAL COMPONENT) or Prensado en seco (dust pressing) (PRODUCT-PROCESS).

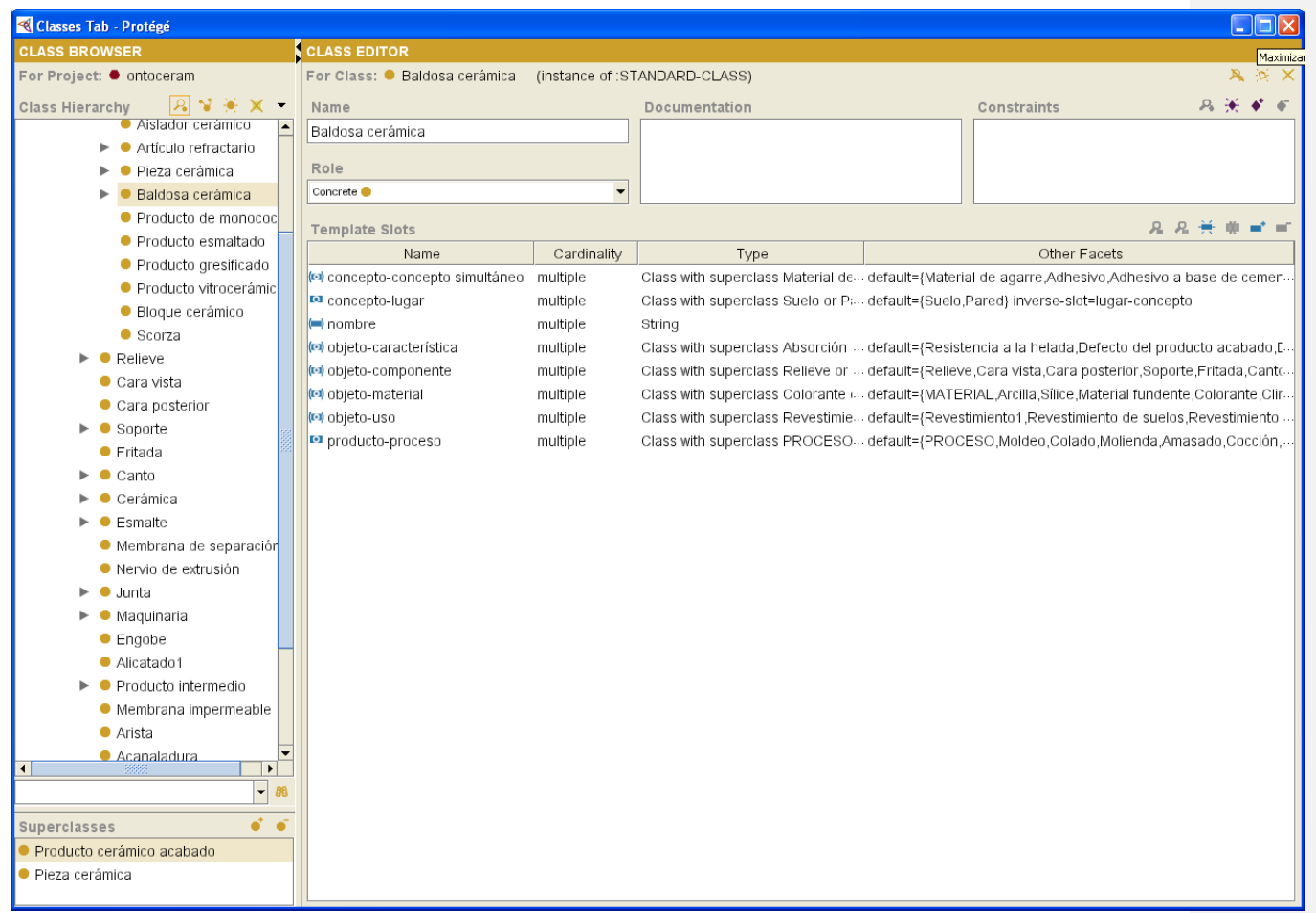

Figure 1. Introduction of the concept Baldosa cerámica (Ceramic tile) 


\subsection{Example of onomasiological query}

Finally, in this section we will show an example of how formalizing and introducing information about conceptual relationships using an ontology editor allows to make onomasiological queries about finished ceramic products.

Let us assume that we want to know which floor tiles are produced by dust pressing. The query in natural language could be expressed as follows:

Which ceramic floor tiles are produced by dust pressing?

If we apply the notation $\boldsymbol{a} \mathbf{R} \boldsymbol{b}$, presented above, $\boldsymbol{a}$ represents the concept ceramic floor tile, which is a ceramic part and $\boldsymbol{b}$ represents the process by which it is produced, that is, dust pressing. The conceptual relationship (R) that links both concepts is the PRODUCT-PROCESS relationship, included in the catalogue as the inverse of the argumental relationship PROCESS-PRODUCT. The question can be formalized as follows:

\section{ceramic floor tile (a) PRODUCT-PROCESS (R) dust pressing (b)}

The PRODUCT-PROCESS relationship holds between entities (products) and activities (processes).

As we have seen in the previous section, the concept ceramic floor tile has been introduced in the database in the hierarchy of concepts represented through the Class component of the ontology editor Protégé. This concept has been assigned a relation slot PRODUCT-PROCESS with certain values, also included as concepts in the database, such as dust pressing or extrusion, for example. The hyponyms of ceramic floor tile have inherited these values, which have been restricted to the corresponding process.

With this information introduced in the conceptual database, it is possible to devise an onomasiological query called dust-pressed ceramic floor tiles using the Protégé Queries function. As can be seen in the screenshot in Figure 2, we can develop a query by restricting the domain of the relationship to the concept Ceramic floor tile, and can state as a search criterion that the value of the PRODUCT-PROCESS slot must be the concept Dust pressing. At this stage of the research, the query yields three results, which are glazed ceramic flooring, ceramic flooring and porcelain stoneware floor tiles, which are terms used to refer to the concepts Stoneware flooring and Porcelain stoneware floor tiles, which 
are subclasses of Ceramic floor tile. Therefore, the system includes in the answer to the query the terms that refer to the hyponyms of ceramic floor tile in which the range of the PRODUCT-PROCESS slot has been restricted to the value Dust pressing.

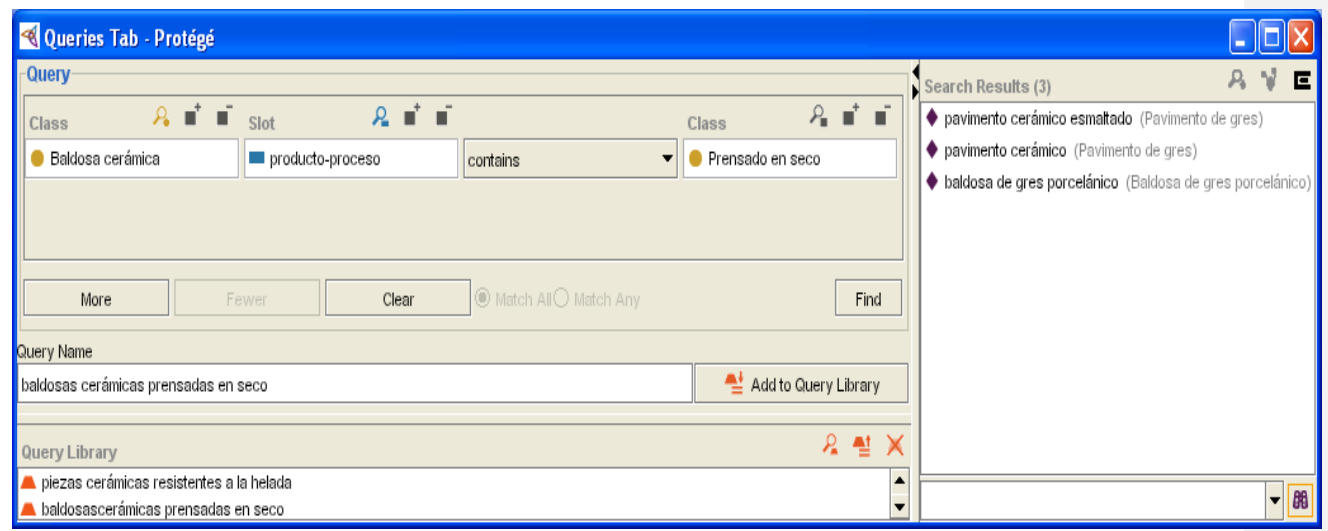

Figure 2. Result of the search dust-pressed ceramic floor tile.

In this case, the Queries Tab function in Protégé is a valid tool to search terms represented by Instances in our conceptual database using criteria which relate the concepts represented by the Class component and linked through the Slot component.

\section{Discussion}

With this example we have shown how the structuring of information about the relationships between concepts using an ontology editor enables to query in an onomasiological way. However, we are aware of the fact that one single query is not enough to prove the validity of the model. In our empirical research a set of ten queries in which different ways of retrieving information about conceptual relationships were considered. For example, the possibility of enquiring about which functional components make up a ceramic tile, which ceramic parts have a particular characteristic or are used for a particular purpose. In all cases, the information formally stored in the conceptual database allows for the retrieval of information as long as the data are correctly introduced. 
Apart from the Queries function, Protégé provides the user with another function called the PAL Queries, which allows to consult ontologies using the so-called Protégé Axiom Language (PAL). This axiom language is used to write and store logical restrictions and queries not only about data introduced as Instances, but also those stored as Classes and Slots. However, in order to make questions using PAL, advanced knowledge of programming languages is required. Therefore, even though this function has advantages, we have not analyzed its full possibilities at this stage of the research.

There are other aspects that still need some refinement. First, although the properties of relationships are explicitly indicated in the slots that represent relationships in the conceptual database, a way of making deductions is still to be developed. In this way, for example, the computer should infer that if a relationship has an inverse relationship, then it holds in both directions. Therefore, if we have related ceramic floor tile and dust pressing through the PRODUCT-PROCESS slot, the ontology editor should assign directly the slot PROCESS-PRODUCT and its value to the class dust pressing.

Second, the inheritance mechanism in Protégé implies that the full set of slots and its values of a hypernym are inherited by each and every hyponym, and the actual values need to be restricted manually.

However, the example shown above illustrates how queries created and executed with the Queries Tab function allow the retrieval of information about the relationships between concepts structured with the help of the Protégé editor following the proposed model of formal description.

\section{Conclusion}

This article aimed at showing that the formal definition of relationships by means of their properties and the conceptual classes they link, helps in the development of queries based on conceptual information. Implementing each of these relationships in the ontology editor Protégé will enable us to perform this type of queries.

Some ground has been covered in the study of the formal description of conceptual relationships from the point of view of terminology using resources from knowledge 
engineering. However, this study has some limitations. First, only finished ceramic goods have been considered, whereas activities and characteristics have not been analyzed in depth. That is the reason why some kinds of relationships have yielded no examples in our empirical analysis.

Second, our proposal for describing conceptual relationships in a formal way needs further development in the implementation in the ontology editor Protégé.

Third, issues such as the reusability of the conceptual database in other applications need to be tackled. The original aim of the conceptual database determines its structure and therefore if the database is intended to be used in other applications it may need to be adapted.

In the future, we intend to adapt the ontology editor to fully implement the properties that have been defined for each relationship. The existing Protégé plugins, such as the PAL Queries Tab and the Queries Tab allow for certain searches, but the former is not very user-friendly, whereas the latter only retrieves data stored as Instances and does not take into account the properties implemented in the slot component. The adaptation of these plug-ins or the development of new ones will improve the potential of searches so that the ontology editor can make deductions taking into account transitivity, symmetry, the cardinality of the relationship and the existence of inverse relationships. In this way it will be made possible both to perform onomasiological queries and to develop the conceptual database in a more economic way.

\section{Notes}

${ }^{1}$ This article is a revised version of the unpublished contribution presented by the authors at the "Colloque Terminologie: approches transdisciplinaires" (Terminology: Transdisciplinary Approaches) held in Gatineau, Quebec between May 2nd-4th, 2007.

2 “TXTCERAM. Extracción semiautomática y análisis conceptual formal de términos de la cerámica a partir de un corpus electrónico. Su eficacia y utilidad en la mediación lingüística” (TXTCERAM. Semiautomatic extraction an formal conceptual analysis of ceramics terms extracted from an electronic corpus. Efficiency and usefulness in linguistic mediation), funded by the Generalitat Valenciana (project code: GV05/260).

3 “ONTODIC. Metodología y tecnologías para la elaboración de diccionarios onomasiológicos basados en ontologías. Recursos terminológicos para la e-traducción" (ONTODIC. Methods and technology for the 
elaboration of ontology-based onomasiological dictionaries. Terminological resources for e-translation), funded by the Spanish Ministry of Science and Technology (project code: TSI2006-01911).

${ }^{4}$ For an extensive review of ontological languages see Gómez Pérez et al. (2004) and Staab and Studer (2004).

5 Conferences and workshops such as LREC (Language Resources and Evaluation Conference), TIA (Terminology and Artificial Intelligence) and TOTh (Terminologie et Ontologie : Théories et Applications), together with special issues of specialized publications such as Terminology (Ibekwe-SanJuan et al 2005) clearly show the increasing importance of ontologies in the field of terminology.

${ }^{6}$ The TXTCERAM corpus is a monolingual specialized corpus about ceramic industry in Spanish made up by 34 specialized texts which contains 2,444,791 words.

7 The notion of "entity" is similar to what Bittner et al. (2004) call "endurants", that is, entities which exist in full in every instant at which they exist at all. Endurants are the disjoint class of "perdurants" which are entities which unfold themselves over time in successive temporal parts or phases.

${ }^{8}$ Each relationship described formally by means of the template could also be summarized using a relation signature, that is, the specification of the name of the relationship, its domain and its range. For example, the relation signature of the PROCESS-PRODUCT relationship would be PROCESS-PRODUCT:activity->entity.

\section{References}

Alcina, A. In press. "Metodología y tecnologías para la elaboración de diccionarios terminológicos onomasiológicos." In Alcina, A., E. Valero and E. Rambla (eds.). Terminología y sociedad del conocimiento. 33-58. Berna: Peter Lang.

Barrière, C. 2002. "Hierarchical Refinement and Representation of the Causal Relationship." Terminology 8(1), 91-111.

Bittner, T., Donnelly, M and B. Smith. 2004. "Endurants and Perdurants in Directly Depicting Ontologies." AI Communications 17(4), 247-258.

Cabré, M. T. 2004. "Termintegral: una plataforma para la construcción de bases terminológicas y ontologías." Linguistica Antverpiensia, NS, 3, 245-261.

Cruse, A. 1996. Lexical Semnatics. Cambridge: Cambridge University Press.

Dancette, J. and M.-C. L'Homme. 2004. "Building Specialized Dictionaries Using Lexical Functions." Linguistica Antverpiensia, NS, 3, 113-131.

Dean, M. and G. Schreiber. 2004. OWL Web Ontology Language Reference. http://www.w3.org/TR/2003/CR-owl-ref-20030818/. Accessed March 2009. 
Evens, M. (ed.). 1988. Relational Models of the Lexicon. Representing Knowledge in Semantic Networks. Cambridge: Cambridge University Press.

Faber, P. 2002. "Investigar en terminología." In Faber, P. and C. Jiménez (ed.). Investigar en terminología. 3-23. Granada: Comares.

Farquhar, A., Fikes, R. and J. Rice. 1997. "The Ontolingua Server: A Tool for Collaborative Ontology Construction." Journal of Human-Computer Studies 46, 707-728.

Feliu, J. 2004. "Relacions conceptuals i terminologia: anàlisi i proposta de detecció semiautomàtica." Unpublished PhD Thesis, Universitat Pompeu Fabra.

Fellbaum, C. (ed.). 1998. WordNet: An Electronic Lexical Database. Language, Speech and Communication. Cambridge, MA: MIT Press.

Gamper, J., Nejdl, W. and M. Wolpers. 1999. "Combining Ontologies and Terminologies in Information Systems." In Proceedings of the $5^{\text {th }}$ International Congress on Terminology and Knowledge Engineering (TKE '99). 152-168. Innsbruck, Austria.

Gómez-Pérez, A., Fernández-López, M and Ó. Corcho. 2004. Ontological Engineering: With examples from the Areas of Knowledge Management, E-commerce and the Semantic Web. London: Springer.

Gruber, T. 1995. "Toward principles for the design of ontologies used for knowledge sharing." International Journal of Human-Computer Studies 43(5-6), 907-928.

Guarino, N. and C. Welty. 2000. "A Formal Ontology of Properties" In Dieng, R. and O. Corby (eds.). Proceedings of the EKAW-2000: The 12 ${ }^{\text {th }}$ International Conference on Knowledge Engineering and Knowledge Management 1937, 97-112. Berlin/Heidelberg: Springer.

Ibekwe-SanJuan, F., Condamines, A. and M. T. Cabré.. (eds.). 2005. Application-Driven Terminology Engineering. Special issue of Terminology 11(1).

ISO. 2000. ISO 704. Travail terminologique: Principes et méthodes. Geneve: ISO.

Kageura, K. 2002. The Dynamics of Terminology: A Descriptive Theory of Term Formation and Terminological Growth. Amsterdam: John Benjamins.

Lassila, O. and R. Swick. 1999. Resource Description Framework (RDF). http://www.w3.org/TR/PR-rdf-syntax/. Accessed March 2009.

Lyons, J. 1977. Semantics. Cambridge: Cambridge University Press.

Madsen, B. N., Thomsen, H. E. and C. Vikner. 2002. "The Caos Project - Computer Aided Ontology Structuring." In Galia, A., Corbett, D. and U. Priss (eds.). Foundations and Applications of Conceptual Structures - Contributions to ICCS. 29-33. Bulgarian Academy of Sciences, Bulgaria.
Comentari [ALS3]: Please, supply the names of all the authors.

Comentari [ALS4]: Please, supply the names of all the authors.

Comentari [ALS5]: Please, supply the names of all the authors.

Formatat: Español (España,

internacional)

Comentari [ALS6]: Part of the title

missing.

Comentari [ALS7]: This author is not cited in the text. Supply all the authors names.

Comentari [ALS8]: Please, supply the names of all the authors.

Comentari [ALS9]: Please, supply the names of all the authors. 
Meyer, I., Skuce, D., Bowker, L. and Eck, K. 1992. "Towards a New Generation of Terminological Resources: An Experiment in Building a Terminological Knowledge Base." COLING 92. 14th International Conference on Computational Linguistics, August 23-28, 1992, Nantes, France. 956-960. Nantes, France.

Moreno Ortiz, A. 2002. "Representación de la información terminológica en ONTOTERM®: un sistema gestor de bases de datos terminológicas basado en el conocimiento." In Faber, P. and C. Jiménez (eds.). Investigar en terminología. 25-70. Granada: Comares.

Nirenburg, S. and V. Raskin. 2004. Ontological Semantics. Cambridge, MA: MIT Press.

Nuopponen, A. 2005. "Concept Relations: An Update of a Concept Relation Classification." In Madsen, B. N. and H. Erdman (eds.). 7th International Conference on Terminology and Knowledge Engineering, TKE 2005. 1, 127-138. Copenhagen: Association for Terminology and Knowledge Transfer.

Oster, U. 2005. Las relaciones semánticas de términos polilexemáticos: estudio contrastivo alemánespañol. Frankfurt am Main: Peter Lang.

Otman, G. 1996. Les représentations sémantiques en terminologie. Paris: Masson.

Sager, J. C. 1990. A practical course in Terminology Processing. Amsterdam/Philadelfia: John Benjamins.

Sager, J. C. and K. Kageura. 1994/1995. "Concept Classes and Conceptual Structures: Their Role and Necessity in Terminology." Actes de Langues Française et de Linguistique (ALFA): Terminology and Special Linguistics 7/8, 191-216.

Smith, B. 1998. "The Basic Tools of Formal Ontology." In Guarino, N. (ed.). Formal Ontology in Information Systems. 19-28. Amsterdam: IOS Press.

Soler, V. and A. Alcina. 2008. "Patrones léxicos para la extracción de conceptos vinculados por la relación parte-todo en español." Terminology 14(1), 99-123.

Sowa, J.F. 2000. Knowledge Representation: Logical, Philosophical, and Computational Foundations. Pacific Grove: Brooks/Cole.

Staab, S. and R. Studer. 2004. Handbook on Ontologies. Berlin: Springer.

Stanford Medical Informatics. 2009. The Protégé Ontology Editor and Knowledge Acquisition. http://protege.stanford.edu/. Accessed January 2009.

Temmerman, R. and K. Kerremans. 2003. "Termontography: Ontology Building and the Sociocognitive Approach to Terminology Description." In Hajicová, E., Kotešovcová, A. and J. Mírovský. (eds.). CIL17. Prague: Matfyzpress.
Comentari [ALS10]: Please, supply the names of all the authors.

Comentari [ALS11]: Supply full name.

Formatat: Inglés (Reino Unido)

Comentari [ALS12]: Supply full name alongside.

Comentari [ALS13]: Please, supply the names of all the authors. 
Weissenhofer, P. 1995. Conceptology in Terminology Theory, Semantics and Word-Formation. Vienna: TermNet.

Winston, M. E., Chaffin, R. D. Herrmann. 1987. "A Taxonomy of Part- Whole Relations." Cognitive Science 11, 417-444.

Author's addresses

Nava Maroto

Traducción e Interpretación

CES Felipe II, Universidad Complutense de

Madrid

C/ Capitán, s/n

E-28300 Aranjuez

+34918099200

mnmaroto@cesfelipesegundo.com

\author{
Amparo Alcina \\ Profesora Titular de Universidad, Traducción e \\ Interpretación \\ TecnoLeTTra Team, Departamento de Traducción \\ y Comunicación \\ Facultad de Ciencias Humanas y Sociales \\ Universitat Jaume I \\ Campus del Riu Sec \\ E-12071 Castellón de la Plana \\ +34964729759 \\ alcina@trad.uji.es \\ http://tecnolettra.uji.es/
}

Comentari [ALS14]: Please, supply the names of all the authors.

About the authors

...

Nava Maroto teaches Terminology and Documentation for translators at the Universidad Complutense of Madrid (Spain). She also takes part at the master's degree on Translation Technology and Localization at the Universitat Jaume I of Castellón (Spain) and other masters' degrees at Universidad de Alcalá de Henares and Universidad de Salamanca (Spain). She is a member of the research team TecnoLeTTra and collaborates in the research project ONTODIC. She has worked as a terminologist at the European Commission (EURODICAUTOM) and other projects of terminology management.

Amparo Alcina is a Senior Lecturer at the Universitat Jaume I of Castellón (Spain) where she teaches Translation Technology and Terminology to 
translators. She is the director of the master's degree in Translation Technology and Localization. She coordinates the research team TecnoLeTTra (http://tecnolettra.uji.es) with a focus on language, terminology and translation technology. She leads the research project ONTODIC, which aims to create onomasiologic dictionaries based on ontologies, as well as other research and educational projects on digital dictionaries, specialized corpora or translation memories. 
Annex 1. Catalogue of conceptual relationships considered in this research.

\begin{tabular}{|c|c|c|c|c|c|c|c|c|}
\hline $\begin{array}{ll}\text { GROUP } & \text { OF } \\
\text { CONCEPTUAL } & \\
\text { RELATIONSHIPS } & \end{array}$ & $\begin{array}{l}\text { CONCEPTUAL } \\
\text { RELATIONSHIP (R) }\end{array}$ & $\begin{array}{l}\text { domain } \\
\text { (a) }\end{array}$ & range $(b)$ & transitiviy & symmetry & cardinality & inverse relationship & examples \\
\hline \multirow[t]{2}{*}{$\begin{array}{l}\text { LOGICAL } \\
\text { RELATIONSHIPS }\end{array}$} & $\begin{array}{l}\text { HYPERNYM- } \\
\text { HYPONYM }\end{array}$ & $\begin{array}{l}\text { entity } \\
\text { activity } \\
\text { property }\end{array}$ & $\begin{array}{l}\text { entity } \\
\text { activity } \\
\text { property }\end{array}$ & Yes & no & yes & $\begin{array}{l}\text { HYPONYM- } \\
\text { HYPERNYM }\end{array}$ & $\begin{array}{l}\text { acabado } \\
\text { superficial- } \\
\text { engobe; } \\
\text { coeficiente de } \\
\text { fricción- } \\
\text { coeficiente de } \\
\text { fricción dinámico; } \\
\text { calafateado- } \\
\text { calafateado } \\
\text { elastomérico }\end{array}$ \\
\hline & HYPONYM-HYPONYM & $\begin{array}{l}\text { entity } \\
\text { activity } \\
\text { property }\end{array}$ & $\begin{array}{l}\text { entity } \\
\text { activity } \\
\text { property }\end{array}$ & Yes & yes & yes & itself & $\begin{array}{l}\text { cubrecantos- } \\
\text { escuadra; } \\
\text { curvatura-grosor; } \\
\text { colocación con } \\
\text { junta-colocación } \\
\text { sin junta }\end{array}$ \\
\hline MERONYMIC & FUNCTIONAL & entity & entity & yes & no & yes & OBJECT- & arista-baldosa; \\
\hline
\end{tabular}




\begin{tabular}{|c|c|c|c|c|c|c|c|c|}
\hline $\begin{array}{ll}\text { GROUP } & \text { OF } \\
\text { CONCEPTUAL } & \\
\text { RELATIONSHIPS } & \end{array}$ & \begin{tabular}{|l|} 
CONCEPTUAL \\
RELATIONSHIP (R)
\end{tabular} & $\begin{array}{l}\text { domain } \\
\text { (a) }\end{array}$ & range (b) & transitiviy & symmetry & cardinality & inverse relationship & examples \\
\hline \multirow[t]{4}{*}{ RELATIONSHIPS } & COMPONENT-OBJECT & & & & & & $\begin{array}{l}\text { FUNCTIONAL } \\
\text { COMPONENT }\end{array}$ & $\begin{array}{l}\text { olambrilla- } \\
\text { baldosín catalán; } \\
\text { esmalte-producto } \\
\text { acabado }\end{array}$ \\
\hline & $\begin{array}{l}\text { MEMBER- } \\
\text { COLLECTION }\end{array}$ & entity & entity & No & no & yes & $\begin{array}{l}\text { COLLECTION- } \\
\text { MEMBER }\end{array}$ & mosaico-tesela \\
\hline & \begin{tabular}{|l|} 
PORTION-MASS \\
\end{tabular} & entity & entity & Yes & no & yes & MASS-PORTION & -- \\
\hline & MATERIAL-OBJECT & entity & entity & Yes & no & yes & OBJECT-MATERIAL & $\begin{array}{l}\text { sustancia viscosa- } \\
\text { adhesivo; frita- } \\
\text { esmalte; } \\
\text { arena natural-base } \\
\text { de arena }\end{array}$ \\
\hline $\begin{array}{l}\text { MERONYMIC } \\
\text { RELATIONSHIPS }\end{array}$ & STAGE-PROCESS & activity & activity & Yes & no & yes & PROCESS-STAGE & $\begin{array}{l}\text { etapa de gran } \\
\text { fuego-cocción; } \\
\text { desolidarización- } \\
\text { colocación; } \\
\text { ensayo-control de } \\
\text { calidad }\end{array}$ \\
\hline
\end{tabular}




\begin{tabular}{|c|c|c|c|c|c|c|c|c|}
\hline $\begin{array}{ll}\text { GROUP } & \text { OF } \\
\text { CONCEPTUAL } & \\
\end{array}$ & $\begin{array}{l}\text { CONCEPTUAL } \\
\text { RELATIONSHIP (R) }\end{array}$ & $\begin{array}{l}\text { domain } \\
\text { (a) }\end{array}$ & range $(b)$ & transitiviy & symmetry & cardinality & inverse relationship & examples \\
\hline & $\begin{array}{l}\text { CHARACTERISTIC- } \\
\text { ACTIVITY }\end{array}$ & property & activity & No & no & yes & $\begin{array}{l}\text { ACTIVITY- } \\
\text { CHARACTERISTIC }\end{array}$ & -- \\
\hline & SPACE-AREA & entity & entity & Yes & no & no & AREA-SPACE & -- \\
\hline $\begin{array}{l}\text { MERONYMIC } \\
\text { RELATIONSHIPS }\end{array}$ & PART-PART & $\begin{array}{l}\text { entity } \\
\text { activity }\end{array}$ & $\begin{array}{l}\text { entity } \\
\text { activity }\end{array}$ & Yes & yes & yes & itself & $\begin{array}{l}\text { cara vista-arista; } \\
\text { esmalte-soporte; } \\
\text { encolado- } \\
\text { dosificación; } \\
\text { engobe-vidriado }\end{array}$ \\
\hline \multirow[t]{3}{*}{$\begin{array}{l}\text { SEQUENTIAL } \\
\text { RELATIONSHIPS }\end{array}$} & $\begin{array}{l}\text { CONCEPT- } \\
\text { SIMULTANEOUS } \\
\text { CONCEPT (IN SPACE) }\end{array}$ & $\begin{array}{l}\text { entity } \\
\text { activity }\end{array}$ & entity & Yes & yes & yes & $\begin{array}{l}\text { SIMULTANEOUS } \\
\text { CONCEPT (IN SPACE)- } \\
\text { CONCEPT }\end{array}$ & $\begin{array}{l}\text { cocción-horno; } \\
\text { adhesivo- } \\
\text { adherendo }\end{array}$ \\
\hline & $\begin{array}{l}\text { CONCEPT-PLACE IT } \\
\text { GOES TO }\end{array}$ & $\begin{array}{l}\text { entity } \\
\text { activity }\end{array}$ & entity & Yes & yes & yes & $\begin{array}{l}\text { PLACE IT GOES TO- } \\
\text { CONCEPT }\end{array}$ & -- \\
\hline & $\begin{array}{l}\text { CONCEPT- } \\
\text { SIMULTANEOUS } \\
\text { CONCEPT (IN TIME) }\end{array}$ & $\begin{array}{l}\text { entity } \\
\text { activity }\end{array}$ & $\begin{array}{l}\text { entity } \\
\text { activity }\end{array}$ & Yes & yes & yes & Itself & - \\
\hline $\begin{array}{l}\text { SEQUENTIAL } \\
\text { RELATIONSHIPS }\end{array}$ & $\begin{array}{l}\text { PREVIOUS CONCEPT- } \\
\text { SUBSEQUENT } \\
\text { CONCEPT }\end{array}$ & $\begin{array}{l}\text { entity } \\
\text { activity }\end{array}$ & $\begin{array}{l}\text { entity } \\
\text { activity }\end{array}$ & Yes & no & yes & $\begin{array}{l}\text { SUBSEQUENT } \\
\text { CONCEPT-PREVIOUS } \\
\text { CONCEPT }\end{array}$ & - \\
\hline
\end{tabular}




\begin{tabular}{|c|c|c|c|c|c|c|c|c|}
\hline $\begin{array}{ll}\text { GROUP } & \text { OF } \\
\text { CONCEPTUAL } & \\
\text { RELATIONSHIPS } & \end{array}$ & $\begin{array}{l}\text { CONCEPTUAL } \\
\text { RELATIONSHIP (R) }\end{array}$ & $\begin{array}{l}\text { domain } \\
\text { (a) }\end{array}$ & range $(b)$ & transitiviy & symmetry & cardinality & inverse relationship & examples \\
\hline \multirow{3}{*}{$\begin{array}{l}\text { ARGUMENTAL AND } \\
\text { CIRCUMSTANTIAL } \\
\text { RELATIONSHIPS }\end{array}$} & PROCESS-AGENT & activity & entity & No & no & yes & AGENT-PROCESS & -- \\
\hline & PROCESS-PATIENT & activity & entity & No & no & yes & PATIENT-PROCESS & $\begin{array}{l}\text { alicatado-azulejo; } \\
\text { colocación- } \\
\text { baldosa cerámica; } \\
\text { enlucido- } \\
\text { superficie }\end{array}$ \\
\hline & PROCESS-PRODUCT & activity & entity & No & no & yes & PRODUCT-PROCESS & $\begin{array}{l}\text { moldeo-baldosa } \\
\text { cerámica; reacción } \\
\text { química-adhesivo } \\
\text { de resina de } \\
\text { reacción; doble } \\
\text { encolado- } \\
\text { macizado }\end{array}$ \\
\hline \multirow{2}{*}{$\begin{array}{l}\text { ARGUMENTAL AND } \\
\text { CIRCUMSTANTIAL } \\
\text { RELATIONSHIPS }\end{array}$} & PROCESS-STATE & activity & $\begin{array}{l}\text { entity } \\
\text { property }\end{array}$ & No & no & no & STATE-PROCESS & -- \\
\hline & CAUSE-EFFECT & $\begin{array}{l}\text { entity } \\
\text { activity } \\
\text { property }\end{array}$ & $\begin{array}{l}\text { entity } \\
\text { activity } \\
\text { property }\end{array}$ & no & no & yes & EFFECT-CAUSE & $\begin{array}{l}\text { fricción-abrasión; } \\
\text { porosidad abierta- } \\
\text { absorción de agua; } \\
\text { calafateado- }\end{array}$ \\
\hline
\end{tabular}




\begin{tabular}{|c|c|c|c|c|c|c|c|c|}
\hline \multirow[t]{2}{*}{$\begin{array}{ll}\text { GROUP } & \text { OF } \\
\text { CONCEPTUAL } & \\
\text { RELATIONSHIPS } & \end{array}$} & $\begin{array}{l}\text { CONCEPTUAL } \\
\text { RELATIONSHIP (R) }\end{array}$ & $\begin{array}{l}\text { domain } \\
\text { (a) }\end{array}$ & range (b) & transitiviy & symmetry & cardinality & inverse relationship & examples \\
\hline & & & & & & & & sellado hermético \\
\hline \multirow[t]{3}{*}{$\begin{array}{l}\text { ARGUMENTAL AND } \\
\text { CIRCUMSTANTIAL } \\
\text { RELATIONSHIPS }\end{array}$} & $\begin{array}{l}\text { PROCESS- } \\
\text { INSTRUMENT }\end{array}$ & activity & entity & No & no & yes & $\begin{array}{l}\text { INSTRUMENT- } \\
\text { PROCESS }\end{array}$ & $\begin{array}{l}\text { colocación en capa } \\
\text { gruesa-cemento } \\
\text { aditivado; control } \\
\text { de resistencia al } \\
\text { cuarteo-autoclave; } \\
\text { colocación con } \\
\text { junta-mortero }\end{array}$ \\
\hline & PROCESS-METHOD & activity & activity & No & no & yes & METHOD-PROCESS & $\begin{array}{l}\text { fabricación- } \\
\text { extrusión }\end{array}$ \\
\hline & OBJECT-USE & entity & \begin{tabular}{|l|} 
activity \\
property
\end{tabular} & No & no & yes & USE-OBJECT & \begin{tabular}{|ll} 
baldosa- & \\
revestimiento de & de \\
suelos; capa & de \\
desolidarización- \\
aislamiento del \\
soporte & \\
barniz-uso & \\
decorativo &
\end{tabular} \\
\hline OTHER & PHENOMENON- & entity & entity & no & no & yes & MEASURE- & dureza mohs- \\
\hline
\end{tabular}




\begin{tabular}{|c|c|c|c|c|c|c|c|c|}
\hline $\begin{array}{ll}\text { GROUP } & \text { OF } \\
\text { CONCEPTUAL } & \\
\text { RELATIONSHIPS } & \end{array}$ & $\begin{array}{l}\text { CONCEPTUAL } \\
\text { RELATIONSHIP (R) }\end{array}$ & $\begin{array}{l}\text { domain } \\
\text { (a) }\end{array}$ & range (b) & transitiviy & symmetry & cardinality & inverse relationship & examples \\
\hline \multirow[t]{2}{*}{ RELATIONSHIPS } & MEASURE & $\begin{array}{l}\text { activity } \\
\text { property }\end{array}$ & & & & & PHENOMENON & $\begin{array}{l}\text { escala de mohs; } \\
\text { carga de rotura- } \\
\text { newtons }(\mathrm{N})\end{array}$ \\
\hline & $\begin{array}{l}\text { OBJECT- } \\
\text { CHARACTERISTIC }\end{array}$ & entity & property & Yes & no & yes & $\begin{array}{l}\text { CHARACTERISTIC- } \\
\text { OBJECT }\end{array}$ & $\begin{array}{l}\text { baldosa cerámica- } \\
\text { absorción de agua; } \\
\text { azulejo-resistencia } \\
\text { a la helada }\end{array}$ \\
\hline $\begin{array}{l}\text { OTHER } \\
\text { RELATIONSHIPS }\end{array}$ & \begin{tabular}{|l} 
ASSOCIATIVE \\
RELATIONSHIP
\end{tabular} & \begin{tabular}{|l|} 
entity \\
activity \\
property
\end{tabular} & \begin{tabular}{|l|} 
entity \\
activity \\
property
\end{tabular} & No & no & yes & itself & $\begin{array}{l}\text { ensayo-propiedad } \\
\text { de los materiales; } \\
\text { embaldosado } \\
\text { directo-capa de } \\
\text { desolidarización }\end{array}$ \\
\hline
\end{tabular}




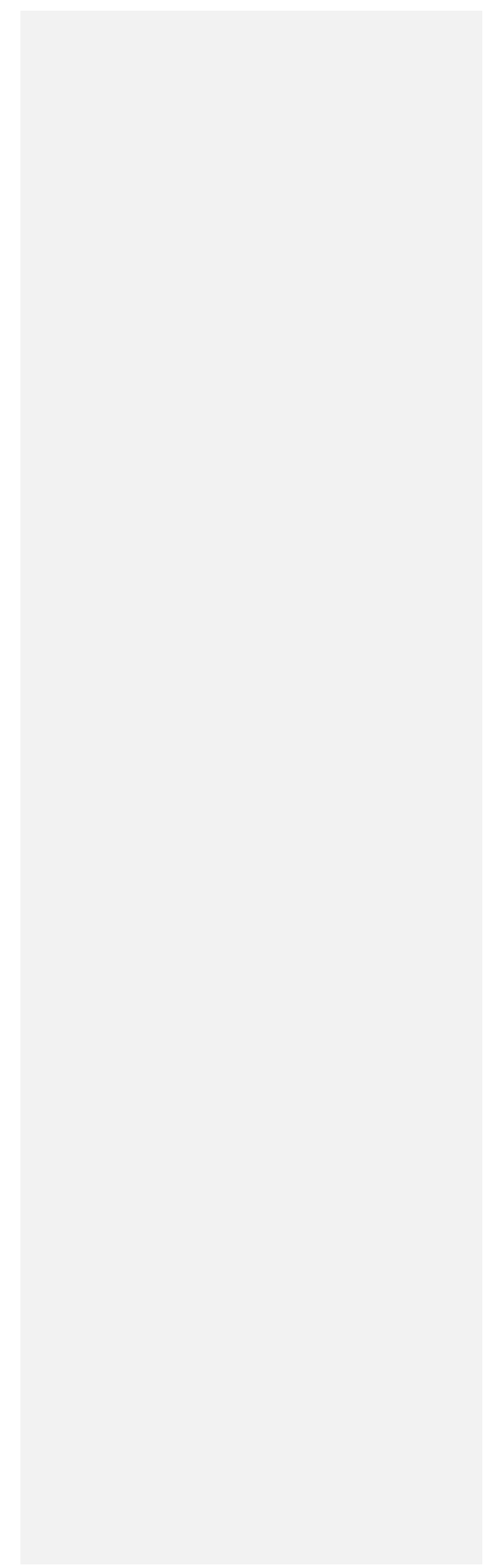

